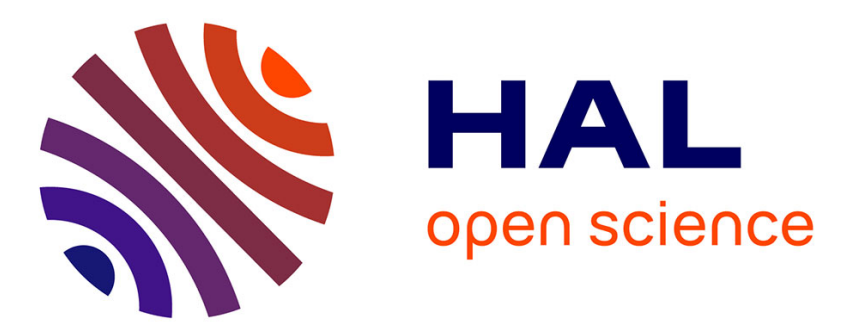

\title{
Developing Supplier Strategies for ETO Companies: A Case Study
}

Mikhail Shlopak, Espen Rød, Oddmund Oterhals

\section{To cite this version:}

Mikhail Shlopak, Espen Rød, Oddmund Oterhals. Developing Supplier Strategies for ETO Companies: A Case Study. IFIP International Conference on Advances in Production Management Systems (APMS), Sep 2016, Iguassu Falls, Brazil. pp.911-918, 10.1007/978-3-319-51133-7_107 . hal01615761

\section{HAL Id: hal-01615761 \\ https://hal.inria.fr/hal-01615761}

Submitted on 12 Oct 2017

HAL is a multi-disciplinary open access archive for the deposit and dissemination of scientific research documents, whether they are published or not. The documents may come from teaching and research institutions in France or abroad, or from public or private research centers.
L'archive ouverte pluridisciplinaire HAL, est destinée au dépôt et à la diffusion de documents scientifiques de niveau recherche, publiés ou non, émanant des établissements d'enseignement et de recherche français ou étrangers, des laboratoires publics ou privés. 


\title{
Developing Supplier Strategies for ETO Companies: A Case Study
}

\author{
Mikhail Shlopak, Espen Rød, and Oddmund Oterhals \\ Møreforsking Molde AS, Molde, Norway \\ \{mikhail.shlopak, espen.rod, oddmund.oterhals\}@himolde.no
}

\begin{abstract}
The purpose of this paper is to present results of applying the Kraljic purchasing portfolio model at three Norwegian engineer-toorder (ETO) companies. The case companies operate in different markets, deliver products of different levels of complexity, and apply different organizational strategies, and differ in several other ways. The paper discusses the ways in which the case companies can develop their supplier strategies based on the executed Kraljic analysis, while emphasizing the importance of taking the companies' distinctive features into consideration..
\end{abstract}

Keywords: SCM · Inter-organizational management · Buyer-supplier relationship - Supplier strategies

\section{Introduction}

Supply chain management is a central topic for ETO companies. Some of them stick to own production, while others have outsourced manufacturing to lowercost countries. The ETO companies vary in size, production volumes, product complexity, the markets they operate in, and in the ways their procurement, production, and project management are organized. However, establishing effective strategies for different suppliers remains highly relevant for all of them. In this paper we look at the three Norwegian ETO companies: two maritime lifting equipment suppliers and one aluminum casting equipment supplier. All three companies are participants in a research project supported by Norwegian Research Council through the MAROFF program. Each case company has categorized its suppliers using the Kraljic purchasing portfolio model. This paper presents the results of this work and discusses the ways in which the case companies can develop their supplier strategies based on the executed analysis.

\section{Theoretical Background}

There are several different classes of manufacturing. It is common to separate between make-to-stock (MTS), assemble-to-order (ATO), make-to-order (MTO), and engineer-to-order (ETO) [1]. According to [2], the commonalities with ETO 
supply chains are that they operate in a project environment and that each product is different.

Many of the frameworks for matching supply chains to the marketplace have been organized around the concept of the "decoupling point". The customer order decoupling point is a stock holding point that separates the part of the supply chain that responds directly to the customer from the part that uses forecast planning. In ETO supply chains, the customer order decoupling point is located at the design stage [2]. Another common feature of the ETO production situation comes in the form of change orders, which change a feature that was decided upon at contract execution. The capability to respond to these kinds of orders is often a prerequisite for success for ETO companies [3]. An analysis of 20 construction projects by [4] shows that 27 percent of non-conformities were related to the work of suppliers and sub-contractors. This indicates a high need to establish good relationships with suppliers. According to [5], there has been an increase in outsourcing by ETO companies, which makes supply chain management strategically important because of the reliance upon suppliers. According to [6], the most critical element of supply strategy is the company's capacity to handle various types of supplier relationships.

Several portfolio models have been developed for purchasing management, including those of [7] and [8]. According to [9], portfolio models can be a tool for management in organizing information and can be used to classify resources and suppliers. If a portfolio model is regarded as an indicator of how to deal with different suppliers, and as an eye-opener for a number of possible action plans, it can provide useful inputs for supply chain decision makers. The matrix by [7] was developed to find strategies regarding products and suppliers based on two dimensions - profit impact and supply risk. The profit impact of a given supply item can be defined in terms of the volume purchased, the percentage of total purchase cost, or the impact on product quality or business growth. Supply risk is assessed in terms of availability of the supply item, the number of suppliers, competitive demand, make-or-buy opportunities, storage risks, and substitution possibilities [7]. [8] used the same matrix, but different dimensions, namely "difficulty of managing the purchasing situation" and "the strategic importance of the purchase." Based on these dimensions, the sup-pliers or components are placed in one of the following categories: "non-critical," "bottleneck," "leverage," or "strategic." The portfolios are visualized in Figure 1.

\section{$3 \quad$ Research Methodology}

The research methodology is a multiple case study research [10]. The data was primarily collected through semi-structured interviews with the case companies' representatives and analysis of secondary sources, such as information from the companies' ERP systems, their steering documents, etc. The methodology suggested by Kraljic [7] was adjusted slightly, as described in paragraph 4.1 below, and was used as a tool for performing supplier evaluation at the case companies. 


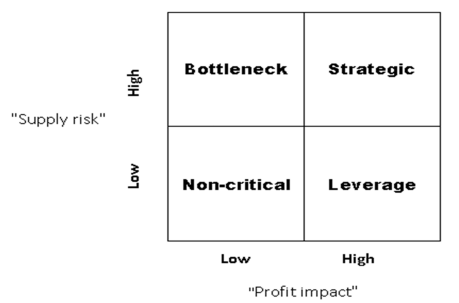

(a) Kraljic Matrix [7]

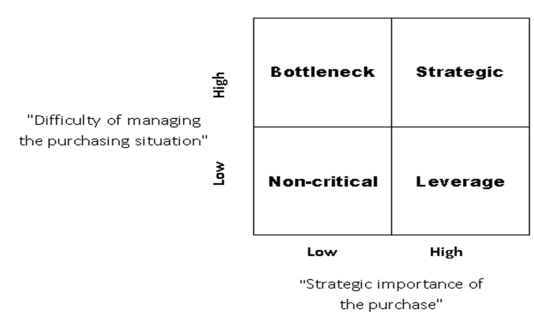

(b) Portfolio Model [8]

Fig. 1. Portfolios according $[7,8]$

\section{Analysis}

\subsection{Supplier Evaluation Procedure}

Prior to the start of the supplier analysis at the case companies, separate meetings of the researchers with representatives of each of the three case companies were organized. At these meetings the researchers presented the Kraljic framework [7] and a step-by-step procedure for performing the analysis. As originally suggested by [7], two dimensions - 'supply risk' and 'profit impact' - were selected as the matrix's horizontal and vertical axes, respectively. A set of evaluation criteria (with weights) was suggested for each of the dimensions (Table 1).

Table 1. Evaluation criteria with weights

\begin{tabular}{|c|c|}
\hline Supply Risk & Profit Impact \\
\hline Product availability $(20 \%)$ & Economic impact $(50 \%)$ \\
\hline Number of potential suppliers $(20 \%)$ & Impact on end product quality $(50 \%)$ \\
\hline Switch costs $(20 \%)$ & \\
\hline Consequence of delay $(20 \%)$ & \\
\hline Competitive structure (20\%) & \\
\hline
\end{tabular}

The product availability criterion is related to the delivery lead time of an item. Whether a product can be purchased in store or if it needs to be engineered and produced will affect the supply risk of the particular item. Number of potential suppliers is related to the number of suppliers that can supply the particular item; whether there is an abundant amount of suppliers or only one will affect the supply risk. The switch cost criterion is the cost of changing from one supplier to another. Consequence of delay is related to whether a delay in delivery of the item will affect the delivery of the final product. The competitive structure criterion has been used to describe the supplier's competitive position in the supply market ("Is it a solid supplier that will survive in the market in the 
future?"). The evaluation criteria that were selected for the dimension profit impact are economic impact and impact on end product quality. Economic impact refers to the economic value of the purchase, while impact on end product quality indicates the impact that the item has on the end product quality. The impact can range from negligible to significant (influencing the quality and safety of the final product).

The first step in the supplier evaluation was for each of the case companies to create lists of their suppliers and supplied items. The companies were given a choice between analyzing suppliers from a specific project or specific product segment, or analyzing all of their suppliers.

The second step was to set a score for each item and/or supplier on each evaluation criterion. The values of criteria could vary between 0 and 10 . The companies were given some freedom in the score setting, regarding what scale to use, and how to assign specific scores to items and/or suppliers.

\subsection{The Case Companies}

Company A is a Norwegian producer of heavy lifting systems for the oil and gas industry. It specializes in producing one-of-a-kind highly technical and complex products. The products are usually engineered from scratch. Procurement is usually handled by the engineers attached to the project. Production takes place at various workshops around the world, usually the ones that are close to the final customer.

Company B is another Norwegian producer of lifting maritime equipment for the offshore oil and gas industry. It primarily produces cranes, in various sizes and applications. The degree of engineering complexity varies over the product line, but they mainly perform engineering based on already designed products. The company has a purchasing department, which is responsible for the procurement of components and fabrication for all projects. Company B produces its products at a small number of workshops, with which it seeks to establish close and long-lasting relationships.

Company $\mathbf{C}$ is a Norwegian producer of cast house solutions for the global aluminium industry. The degree of engineering complexity varies, but the engineering is usually performed based on the company's existing product portfolio. The company has a purchasing department that handles all procurement for the projects. The company produces at several locations globally, but assembly and testing are carried out at its facility in Norway.

\subsection{Supplier Analysis - Company A}

Company A chose to perform the analysis based on one particular project. In the analysis, the company used the evaluation criteria with their respective weights as provided in Table 1, except for one criterion, competitive structure, which was substituted with criterion cooperativeness, referring to service availability for the specific item and the response time from the supplier(s) of the item. The 
results of the categorization of the procured items in the project selected by Company A are presented in Figure 2.

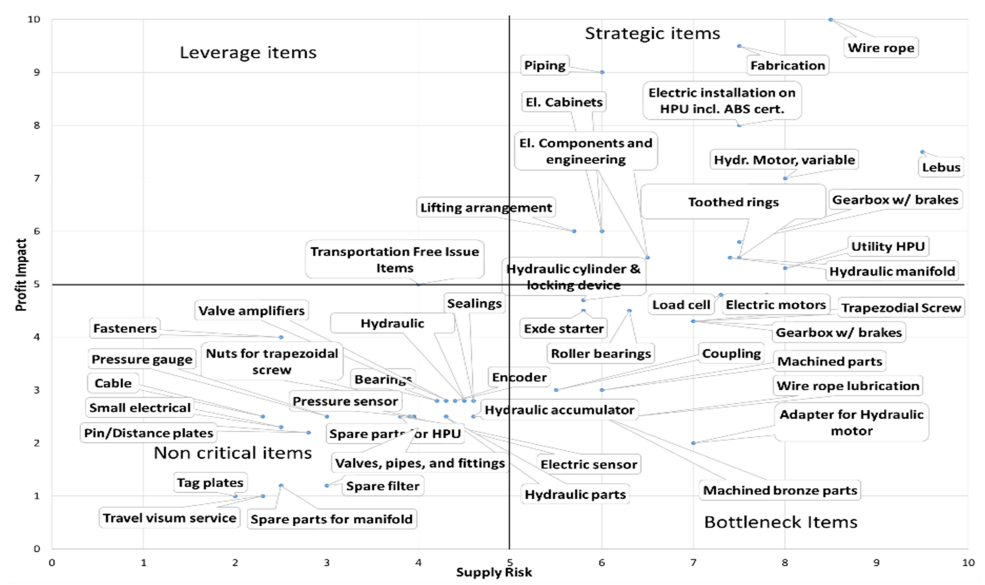

Fig. 2. Kraljic Matrix - Company A

\subsection{Supplier Analysis - Company B}

Company B chose to perform the analysis on a segment of products. It initially created a list of the suppliers it used for this product segment. It chose to perform the analysis based on suppliers and not items or product groups. The scoring of the suppliers (for each supplier, for each criterion) was done by representatives from the purchasing department. The scores were based on the purchasing department representatives' experience and knowledge about the suppliers. These representatives sometimes went back and changed the scores of some suppliers after comparing with the scores of other suppliers. The results of the categorization of the suppliers for a selected segment of Company B's products are presented in Figure 3 (note that, according to confidentiality requirements, the suppliers' names were substituted with the names of items they supply, so some of the items may appear several times on the matrix).

\subsection{Supplier Analysis - Company C}

Company $\mathrm{C}$ chose to execute the supplier analysis based on the entire database of its suppliers. The analysis was executed both on the item groups' level and on the supplier level. Like Company A, Company C used criterion cooperativeness instead of competitive structure when evaluating supply risk. The results of the categorization of Company B's groups of purchased items on the Kraljic matrix are presented in Figure 4. 


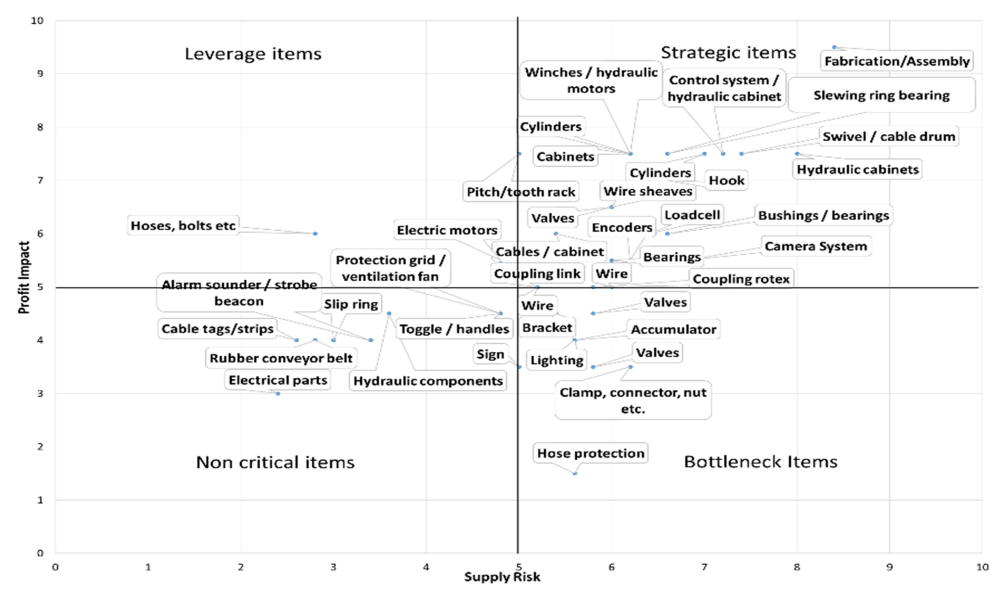

Fig. 3. Kraljic Matrix - Company B

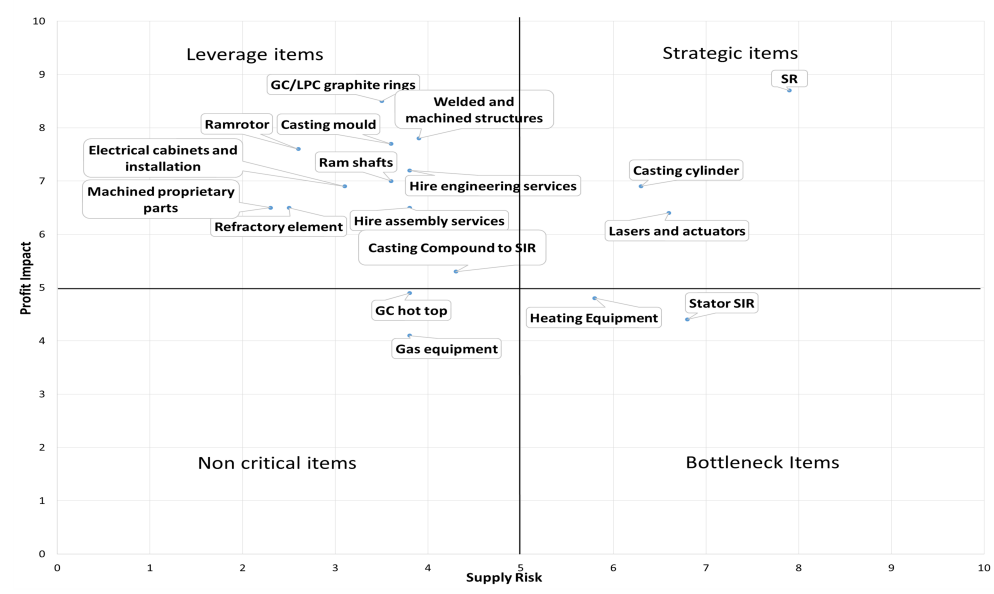

Fig. 4. Kraljic Matrix - Company C

\section{Towards New Supplier Strategies - Discussion}

After completing the mapping of the procured item groups and/or suppliers on the Kraljic matrix, the natural next step is to try to define strategies for the supplies of the items categorized into the four groups: non-critical, leverage, bottleneck, and strategic.

According to [8], the key term for products in the non-critical category is standardization, which implies having a supplier relationship that basically manages itself. The focus must be on reducing administrative costs. For the products in the bottleneck category, some sort of relationship with supplier should be established, and cooperation in value analysis should be done in order to lower 
the cost of operations. For the products in the leverage category, it is important to identify the value added of the purchase and leverage volume across product lines and suppliers in order to lower the material costs. The goal is to create mutual respect in the supplier relationship and communicate requirements further into the future. For the products in the strategic category, it is important to establish a close relationship with the supplier and to focus on early supplier involvement and joint developments of products and services.

[11] suggested another way to establish new supplier strategies. They argued that for each item group, two kinds of strategic directions could be distinguished: (1) actions to hold the same positions in the matrix, and (2) actions to pursue other positions in the matrix. A total of nine strategic directions were proposed: (1) "Decomplex the product, find a new supplier" or (2) "Accept the dependence on a supplier, assurance of supply" (bottleneck items); (3) "Pooling of requirements" or (4) "Individual ordering, efficient processing" (non-critical items); (5) "Exploit buying power, maintain a partnership of convenience" or (6) "Develop a strategic partnership" (leverage items); (7) "Maintain a strategic partnership"; (8) "Accept a locked-in partnership" or (9) "Terminate a partnership, find a new supplier" (strategic items) [11].

In the ETO setting, it is common not only for the end product to be customized, but also for some of the components delivered by suppliers to be tailored to the customers' needs. In this respect, the level of detail of the component specifications sent to the supplier is important. [9] distinguished between how specifications should be developed for each item category in the Kraljic matrix. In the non-critical category, specifications of products should follow an industry standard. For leverage components, rough specifications should be developed with parameters such as function, quality, cost, and system fit. The supplier should be given the freedom to undertake further development and ultimate sealing of these components. In the case of bottleneck components, the reduced number of capable suppliers makes it necessary to have collaborative agreements with them. Because of low strategic importance, the supplier can gain responsibility for developing the components' specifications. The buyer should then help the supplier to standardize these components in order to reduce the costs in the entire supply chain. In the case of strategic products, there is need for close relationships with the suppliers and early or even continuous involvement.

The case companies are currently in the process of development of their supplier strategies. In this process, the approach suggested by [11] was taken as the starting point. However, it is clear that there is no one-size-fits-all approach for ETO companies with regard to managing suppliers of the items categorized into the four groups in the Kraljic matrix. Company A works mainly in the "temporary supply chain" environment because their customers are spread all over the world, and it is the company's strategy to fabricate and assemble its products close to the customers. This implies that a long-term strategy to build relationships with suppliers is difficult. Companies B and C, on the other hand, seek to build long-term relationships with their strategic suppliers, particularly with their fabrication suppliers. 


\section{Conclusion}

This paper has presented an application of the Kraljic Matrix at three Norwegian ETO companies. We have described the process of conducting the analysis and presented the results of the analysis, and discussed possible methods to develop strategic directions towards the supplier base. We can conclude that there is no one-size-fits-all approach towards supplier strategies in the ETO setting, and the companies' distinctive features should always be taken into consideration. The feedback received from the case companies points to the effectiveness of the Kraljic approach as a tool for generation or development of supplier strategies.

\section{References}

1. Olhager, J.: Strategic Positioning of the Order Penetration Point. International Journal of Production Economics 85(3), 319-329 (2003)

2. Gosling, J., Naim, M.M.: Engineer-to-order sSpply Chain Management: A Literature Review and Research Agenda. International Journal of Production Economics 122(2), 741-754 (2009)

3. Sjøbakk, B., Thomassen, M.K., Alfnes, E.: Automation in the ETO Production Situation: The Case of a Norwegian Supplier of Ship Equipment. In: International Workshop of Advanced Manufacturing and Automation. Akademika Forlag (2013)

4. Zavadskas, E., Vilutienè, T., Turskis, Z., Šaparauskas, J.: Multi-criteria Analysis of Projects' Performance in Construction. Archives of Civil and Mechanical Engineering 14(1), 114-121 (2014)

5. Hicks, C., McGovern, T., Earl, C.F.: Supply Chain Management: A Strategic Issue in Engineer to Order Manufacturing. International Journal of Production Economics 65(2), 179-190 (2000)

6. Gadde, L.E., Snehota, I.: Making the Most of Supplier Relationships. Industrial marketing management 29(4), 305-316 (2000)

7. Kraljic, P.: Purchasing Must Become Supply Management. Harvard business review 61(5), 109-117 (1983)

8. Olsen, R.F., Ellram, L.M.: A Portfolio Approach to Supplier Relationships. Industrial marketing management 26(2), 101-113 (1997)

9. Nellore, R., Söderquist, K.: Portfolio Approaches to Procurement: Analysing the Missing Link to Specifications. Long Range Planning 33(2), 245-267 (2000)

10. Yin, R.K.: Case Study Research: Design and Methods. Sage publications (2009)

11. Gelderman, C.J., Van Weele, A.J.: Handling Measurement Issues and Strategic Directions in Kraljic's Purchasing Portfolio Model. Journal of purchasing and supply management 9(5), 207-216 (2003) 